\title{
両側二期的手術によって著明な肺機能改善と 不整脈消失を得た巨大肺囊胞症の一例
}

金光 尚樹, 横見瀬裕保, 片倉 浩理, 板東 徹, 大久保憲一
小阪 真二, 寺町 政美, 高橋 豊, 八木 一之, 乾 健二
水野 浩, 青木 稔, 和田 洋巳, 人見滋樹

要 旨
症例は34歳，男性. 労作時呼吸困難（H-JII度）を訴光，胸部X線写真上，両側巨大肺囊胞症を指摘
された. 術前に肺血管造影，換気血流シンチ等の検査を行い，手術による肺機能の改善が期待されたの
で囊胞を二期的に切除，縫縮した. その結果，肺機能の著明な改善を得た. また，術前認められた AV
block と sick sinus syndrome は，ほぼ消失した.

索引用語：巨大気腫性肺囊胞症，二期的手術，洞不全症候群 emphysematous giant bulla, two stage operation, sick sinus syndrome

はじめに

巨大気腫性肺囊胞症は原因については諸説が ある ${ }^{1,2)}$ が徐々に進行し呼吸不全を生じうる疾 患である，我々は，両側に巨大肺囊胞があり， 呼吸不全を呈するに至った症例を経験した．肺 血管造影を行い末梢の血管が良く保存されてい る所見を得たので, 肺囊胞を切除, 縫縮するこ とにより肺機能の改善が得られると判断した. 両側とも肺囊胞は巨大であったので手術は二期 的に行った. 術後, 著明な肺機能の改善を得た. 更に，術前に認められていた AV block, sick sinus syndrome の著しい改善をみた. 巨大気腫 性肺囊胞症と不整脈々の間に因果関係があった と考えられる. このような例の報告は未だ無く, 興味深いので報告する。

京都大学胸部疾患研究所 胸部外科 原稿受付1993年 3 月 16 日 原稿採択1993年10月14日
症例

症 例: 34 歳, 男性. 水泳教師.

主 訴：労作時呼吸困難 (Hugh-Jones II 度)

既往歴：20歳時, 右自然気胸. トロッカー挿 入により治療された.

家族歴：特記すべきこと無し．

現病歷：1986年, 検診にて胸部異常陰影を指 摘されたが，放置していた。1991年 1 月，腹部 圧迫感と労作時呼吸困難を自覚し近医受診した。 胸部X線写真にて両側巨大ブラを指摘された. 某病院に入院, 精査をうけるも手術適応なし, 経過観察とされ退院した. 患者が手術を希望し たため，1991年 3 月，当科を紹介受診. 尚，呼 吸困難は徐々に進行し, 当科を紹介され受診時, Hugh-Jones II 度の呼吸困難を訴えていた.

喫煙歴：1 日40本を16年間.

現 症: 身長 $175 \mathrm{~cm}$, 体重 $65 \mathrm{~kg}$. 聴診にて両 側上中胸部に呼吸音減弱を認めた。心雑音なし.

血液, 生化学検查: ChF，Ccr 軽度低下を除 


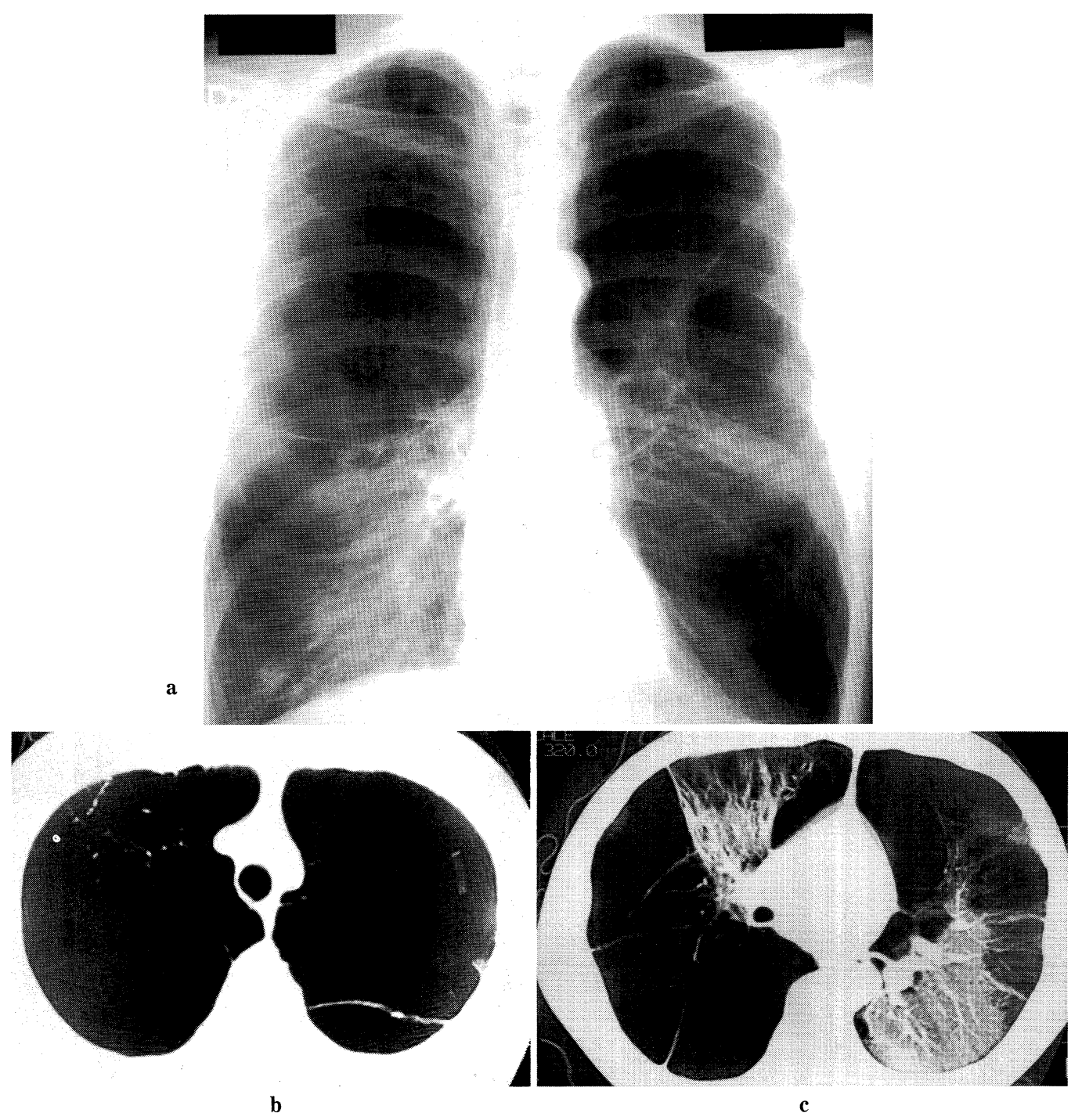

Fig. 1 Chest roentgenogram (a) and CTscan (b, c) on admission showing bilateral giant bullae.

いて正常. 他院にて測定した $\alpha_{1}$ antitrypsin は $193 \mathrm{mg} / \mathrm{d} l$ で正常範囲内であった.

動脈血ガス分析: $\mathrm{PaO}_{2} 64.7$ torr. $\mathrm{PaCO}_{2}$ 40.6 torr, pH 7.427

肺機能検査 : VC $3.91 l$, \% VC $93.8 \%$, $\mathrm{FEV}_{1.0} 1.43 l, \mathrm{FEV}_{1.0} \%(\mathrm{G}) 47.2 \%$ にて高度 の閉塞性換気障害を認めた.

入院時胸部 $\mathbf{X}$ 線写真: 両側上中肺野に胸腔 の $50 \%$ 以上を占める巨大ブラを認める（Fig. 1a).
胸部CT：上肺野には血管陰影を認めず, 中肺 野でも右側には背側に, 左側には腹側に巨大ブ ラを認める (Fig. 1b，c).

肺動脈造影：末梢の小血管，毛細血管がよく 保存されている (Fig. 2).

換気血流シンチ：右中肺野, 左上肺野で換気, 血流とも著明に低下して扬り, 洗い出し時間も 右下肺野を除き著明に延長している.

心電図：肺動脈造影時にVPC 多発したため, Holter 心電図検査を行った. 夜間唾眠時に AV 


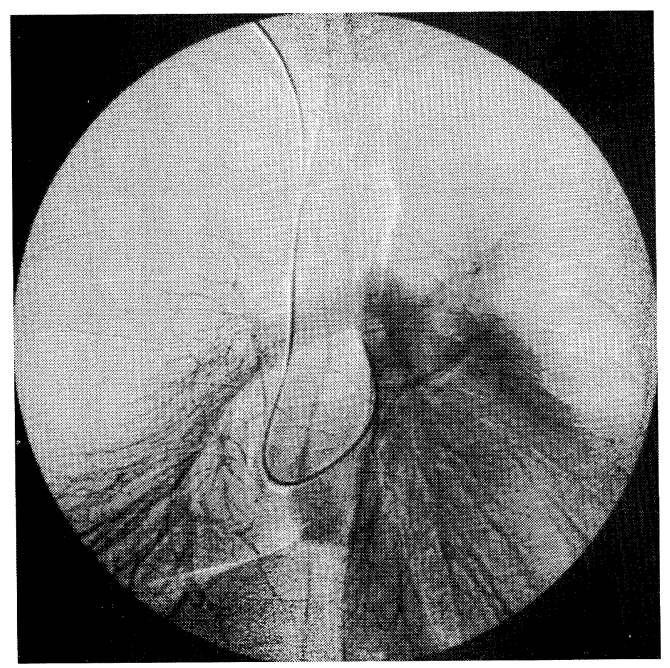

Fig. 2 Pulmonary angiography shows adequately patent peripheral arteries and veins. block, sick sinus syndrome が認められた (Fig. 3a).

\section{経過}

肺動脈造影の結果から，ブラ縫縮術を施行す ることより肺機能の改善が期待された. 臨床症 状があり，かつ患者が手術を強く希望していた ため手術適応ありと判断した。

手術は，ブラが両側とも巨大であるので，も し一期的に行って肺機能が改善しなかったとき のことを考えて二期的に行らことにし，片側の 手術肺の機能改善を確認した後，もら一方の手 術を行うこととした. 右側のブラの方が画像上 巨大であるため，右側を先に行った。両側とも 前方腋窩皮膚切開，第 4 肋間開胸で行い，ブラ 壁を切除し，ブラを縫縮した. 右には $\mathrm{S}^{1} に 20 \times$

a
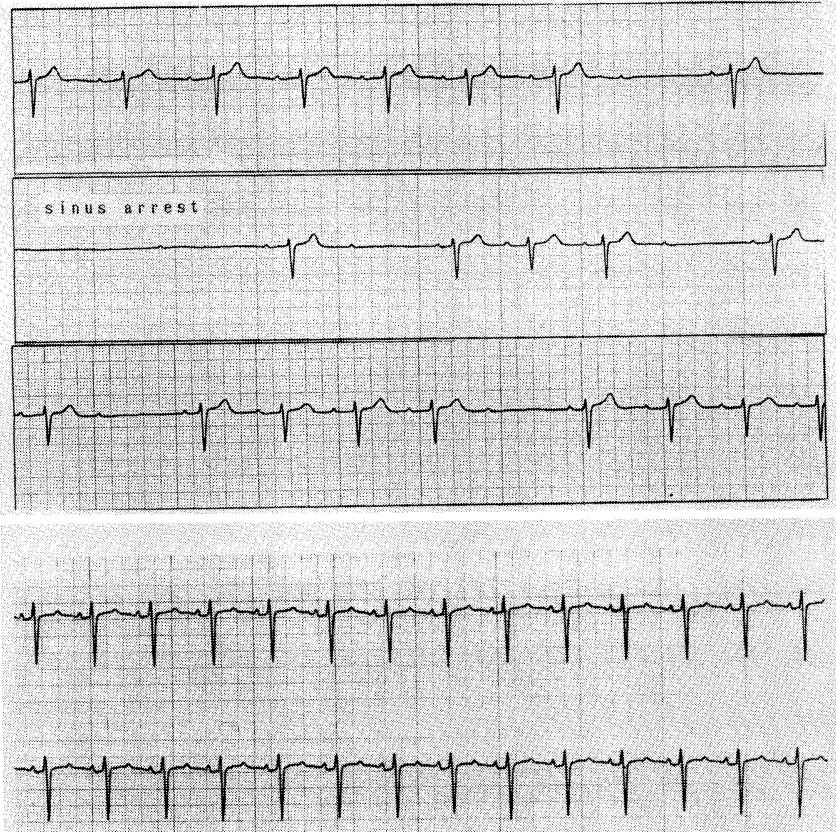

b

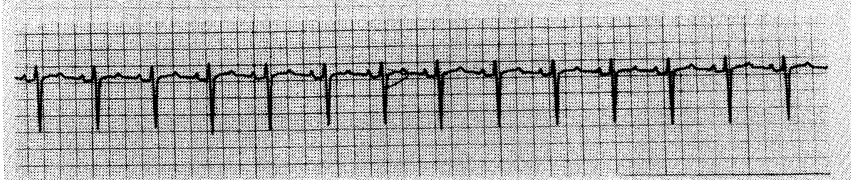

Fig. 3 Preoperative Holter ECG shows AV block and sick sinus syndrome, especially when sleeping at night (a). Postoperative Holter ECG was normal (b). 
$15 \times 15 \mathrm{~cm}, \mathrm{~S}^{2}, \mathrm{~S}^{3}$ にそれぞれ径 $2 \mathrm{~cm}$ のブラ を, 左は $\mathrm{S}^{1+2}$ に径 $15 \mathrm{~cm}, \mathrm{~S}^{6}$ に径 $2 \mathrm{~cm}$ のブラ が認められた. 2 回とも術後合併症として airleakage を認め，1回目は保存的に，2 回目は fibrin glue の胸腔内注入により対処し, 何れも 術後13日目に胸腔ドレーン拔管可能となった.

病理検査の結果, 病変は気腫性囊胞であり malignancy の合併は認められなかった. 右側 の術後の胸部写真にて左側のブラの増大や自然
気胸などは認められなかった。左側術後の胸部 写真で術後, 圧迫されていた両側の肺の再膨張 は良好である (Fig. 4a). 胸部 CT でも肺の再 膨張が良好であることがよくわかる（Fig. 4b， c).

手術の 4 カ月後の肺機能はVC $5.01 l, \% \mathrm{VC}$ $120.1 \%, \mathrm{FEV}_{1.0} 3.07 l, \mathrm{FEV}_{1.0} \% 72.8 \%$ で あり, 6 カ月後の動脈血ガス分析では $\mathrm{PaO}_{2}$ 81.7 torr, $\mathrm{PaCO}_{2} 43.0$ torr, $\mathrm{pH} 7.403$ で，と a

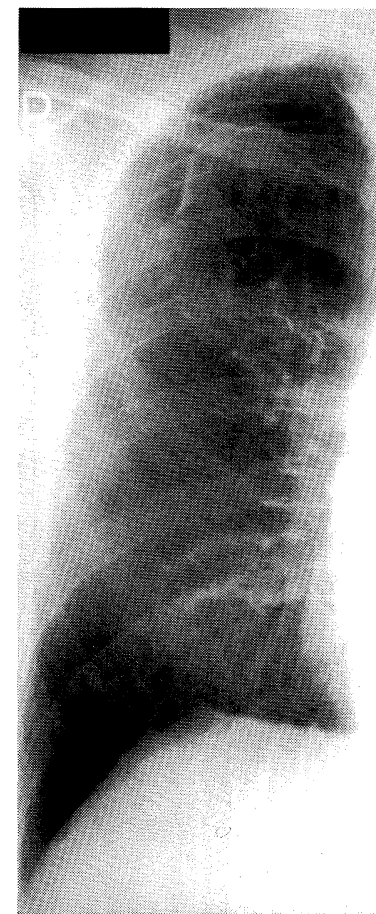

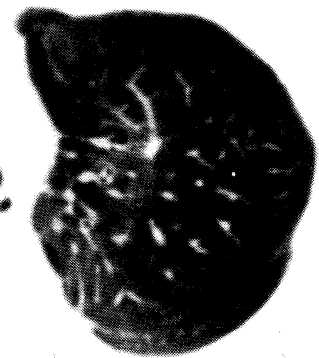
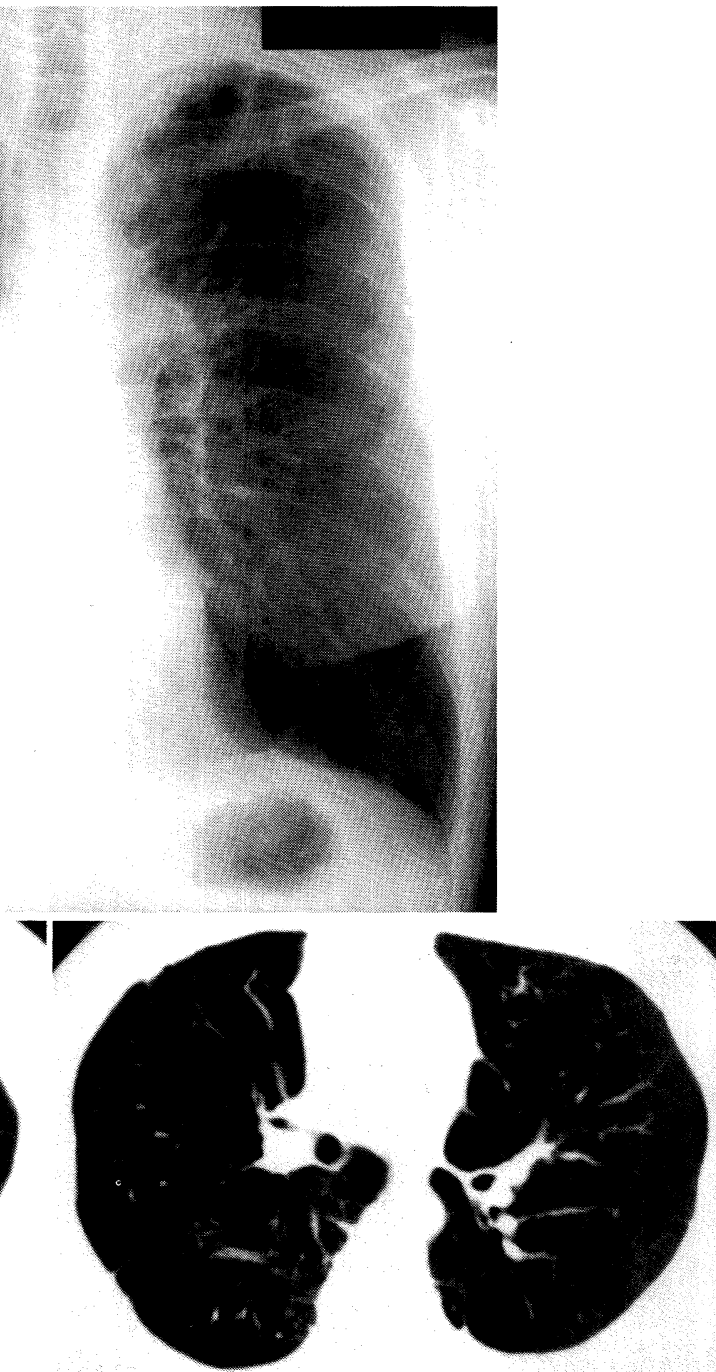

c

Fig. 4 Postoperative chest roentgenogram (a) and CTscan (b, c) show good expansion of the compressed lung. 
くに 1 秒量, 1 秒率, $\mathrm{PaO}_{2}$ の著しい改善を認め た. 術後の換気シンチにて両側上中肺野の低換 気の改善がみとめられ, 洗い出し時間も著明に 短縮した. 術前の Holter 心電図にて，とくに 深夜の睡眠中に AV block と sick sinus syndrome を認めたが, これらの不整脈は 2 回目の 術後, 注济消失した (Fig. 3b). 患者は術後, 39 日目に退院. 退院時, 労作時呼吸困難は消失し, 現在では水泳教師の職に復帰している.

\section{考案}

両側巨大ブラの手術適応としては，1)呼吸困 難などの症状があること，2)ブラが進行性に増 大寸ること, 3)術後, 肺機能の改善が予想でき ること, 4)気胸, 出血, 感染, 癌の合併などが, 諸家の一致するところと思われる ${ }^{1,7)}$.

術後の肺機能改善の有無を予測するにはいく つかの方法が考案されている. 1)肺血管造影に て小血管, 毛細血管がよく保存されているも の ${ }^{1,3)}$. 2)肺換気血流シンチでブラとその底部の 肺との交通性が良い交通性ブラと，それが少な い非交通性ブラとに分類した場合，非交通性の ものが比較的, 肺機能の改善が望める ${ }^{2,4,9)}$. 手 た, $\Delta \mathrm{N}_{2}$ はブラ以外の肺の機能を反映するもの として術後肺機能を予測する上で, 良い指標に なるという ${ }^{5}$. 横隔膜上にある巨大ブラは, ブラ 切除により肺機能改善が期待される.これは横 隔膜の運動が良好となり肺の圧迫がとれるため と考光られている ${ }^{6)}$.この症例では肺血管造影 にて小血管, 毛細血管が良く保存されているこ とが確かめられている．肺換気血流シンチでは 平衡相に招いてはブラに一致した部位にも換気 を認め, いわゆる交通性ブラであると予測され た. 実際, 術中所見として, 麻酔バッグの動き に同期してブラの膨張と収縮を認めている。こ の症例では $\Delta \mathrm{N}_{2}$ を測定していない. 両側巨大ブ ラの手術方法については, 一期的に, 胸骨正中 切開により, あるいは両側開胸により行ら方法 と，二期的に行う方法がある.

術後に肺機能が両側ともに低下寸ると非常に 危険である，また，胸骨正中切開によるアプロ 一チは呼吸筋を保存する意味で良いが，ブラが
背側に存在した場合に処理しにくい欠点がある. 一方，二期的に行った場合，一側肺の術中や術 後に, もら一方のブラの急速な増大や, 自然気 胸を生じることがあるという7)。とくに左側を 先に手術した場合に多いという報告がある7 . この症例の場合には，両側ともにブラが巨大で あり, しかも CT で背側にもブラが存在するこ とが判明していたため, 二期的, 両側開胸とし た. 又，呼吸筋の損傷を最小限にするために前 方腋窩切開を選んだ.

反対側ブラの増大や気胸の発生については, この肺への一過性の圧負荷の増大よるものと考 党，一度目には double lumen tube，二度目は univent tube を挿管チューブとして用いて，反 対側への負荷を抑えるよう努力した。 そのため, 合併症としては術後, 一時的に肺㾞を認めたの みであった. 術後肺機能はとくに 1 秒率の著し い改善を認めたが，肺活量も改善を認めている. しかし, 遠隔成績では, 徐々に肺機能の悪化を みることがある，といら報告もあり，これから も厳重な follow up を必要とする. この症例で もら一つ注目すべき点は, AV block, sick sinus syndrome の合併であり, 術後これらの不整脈 が消失したことは，巨大ブラとの間になんらか の因果関係があると考えてよい. この機序とし ては, 胸腔の拡張に伴う迷走神経の過伸展刺激, あるいは低酸素血症による間接的なものが考觉 られる．以前にこのような例の報告は $\alpha_{1}$ antitrypsin 欠損症の肺気腫の患者に $\mathrm{AV}$ block を認めたといら一例がある9のみである. われわれの症例では, His 束心電図等の不整脈 の原因を調べる検査を施行して扔らず，これか らの研究に待つところである.

結 論 : 両側巨大気腫性肺囊胞症の縫縮術を 二期的に行い, 著明な肺機能の改善を得た. そ れと共に術前にみられた AV block と sick sinus syndrome の改善も得られた.

\section{文献}

1）大畑正昭：巨大肺賈胞症について. 日胸 36 : $725-735,1977$.

2）八木一之, 人見滋樹: 囊胞性肺疾患の発生, 進 展, 治療. 呼吸と循環 39：1181-1187, 1991. 
3）桑原 修, 越山健二郎: 手術より顕著な機能改 善が得られた両側性巨大気腫性肺囊胞症. 日胸 外会誌 $31 ： 1176-1180,1983$.

4）八木一之, 小西孝明, 石田久雄, 他: 巨大肺囊 胞症の外科治療成績. 日呼外会誌 5（1）：3644, 1991.

5）太田三徳, 前田昌純, 安光 勉, 他：不均等換 気の指標による巨大肺囊胞症21例の手術前後 の肺機能評価. 日胸外会誌 36 (増)：1902, 1988.

6）千原幸司, 人見滋樹：巨大気腫性肺囊胞症の病 型分類と肺機能 (1)，(2). 日呼外会誌 $3: 511$
$-535,1989$.

7）関 正威：自然気胸と巨大肺囊胞の外科. 外科 診断 $24: 317-328,1982$.

8) Laros C D, Gelissen H J : Bullectomy for giant bullae in emphysema. J Thorac Cardiovasc Surg 91: 63-70, 1986.

9) Mc'Donald C F, Stewart P M : Emphysema, cirrhosis, and heart block in young patient with partial $\alpha_{1}$ antitrypsin deficiency (PiMZ phenotype). British Medical Journal 291 : 1673-1674, 1985.

\section{Greately improved respiratory function after two stage operation for bilateral giant emphysematous bullae; a case report}

Naoki Kanemitsu, Hiroyasu Yokomise, Hiromichi Katakura, Toru Bandou, Kenichi Ohkubo Shinji Kosaka, Masami Teramachi, Yutaka Takahashi, Kazuyuki Yagi, Kenji Inui Hiroshi Mizuno, Minoru Aoki, Hiromi Wada, Shigeki Hitomi

Department of Thoracic Surgery, Chest Disease Research Institute, Kyoto University, Kyoto, Japan

A 34-year-old man admitted with dyspnea on effort as his chief complaint. A chest X-ray film showed bilateral giant bullae. A pulmonary angiogram showed adequate patency of the peripheral pulmonary vessels, so significant improvement of respiratory function was expected. He underwent two-stage bullectomy and plication successfully. Preoperative respiratory function test results were: $\mathrm{VC} 3.91 \mathrm{l}, \% \mathrm{VC} 93.8 \%, \mathrm{FEV}_{1.0} 1.43 l, \mathrm{FEV}_{1.0} \% 47.2 \%, \mathrm{PaO}_{2} 64$. 7torr, $\mathrm{PaCO}_{2}$ 40.6torr, pH 7.427. Four months after surgery the results were: VC $5.01 l \% \mathrm{VC}$ $120.1 \%, \mathrm{FEV}_{1.0} 3 . .70 l, \mathrm{FEV}_{1.0} \%$ 72.8\%, $\mathrm{PaO}_{2}$ 81.7torr, $\mathrm{PaCO}_{2}$ 43.0torr, $\mathrm{pH}$ 7.403. Another remarkable finding was that his preoperative Holter ECG showed sick sinus syndrome, but immediately after the two stage operation it had disappeared. 